\title{
Refuge
}

Canada's Journal on Refugees

revue canadienne sur les réfugiés

\section{Asylum after Empire: Colonial Legacies in the Politics of Asylum Seeking, by Lucy Mayblin}

\section{Estella Carpi}

Volume 34, Number 2, 2018

URI: https://id.erudit.org/iderudit/1055591ar

DOI: https://doi.org/10.7202/1055591ar

See table of contents

Publisher(s)

Centre for Refugee Studies, York University

ISSN

0229-5113 (print)

1920-7336 (digital)

Explore this journal

Cite this review

Carpi, E. (2018). Review of [Asylum after Empire: Colonial Legacies in the Politics of Asylum Seeking, by Lucy Mayblin]. Refuge, 34(2), 158-160.

https://doi.org/10.7202/1055591ar

This document is protected by copyright law. Use of the services of Erudit (including reproduction) is subject to its terms and conditions, which can be viewed online.

https://apropos.erudit.org/en/users/policy-on-use/ 
certain refugee groups as "more vulnerable" or important than another. However, funding prerogatives hinder more critical, alternative refugee research.

Throughout, the chapters take care to balance theoretical frames with ethnographic description and qualitative research. In the second section, the chapters move into more detail on integration practices themselves. In particular, Mantei takes a feminist perspective of fabric arts as gendered text among Karen women moving from Burma to Thai refugees camps to resettlement in Saskatchewan, Canada. Weaving becomes a way for women to connect to the past, even as the weaving shifts in meaning and utility for women. Holt and Laitsch's chapter examines settlement practices in schools for refugee students adjusting to the new education system. They look at the experience of settlement workers, providing specific areas for improvement as well as highlighting the role that schools play. Sienkiewicz and Nichols keep the focus on institutional models, charting the evolution of settlement houses in the United States. Drawing on ethnographic research at a resettlement complex in North Carolina, they argue that increased communication and targeted recruitment are required to bolster integration into communities across ethno-national and racial divides.

Key strengths of this book are the authors' suggestions for pragmatic approaches of reform. Hynie et al. develop a holistic model of integration drawn from a refugee resettlement study in six Ontario cities. They stress the importance of considering subjective variables, such as feelings of belonging and of being at home, as part of a larger holistic integration model. Bose, on the other hand, looks at the successes and challenges of a mutual aid association staffed primarily by refugees in Vermont. He makes recommendations to improve the resettlement experience, centring his methodology on participatory action research. Poteet provides an uplifting conclusion to the book, considering a more expansive notion of integration among Central American male youth in Toronto of refugee origin. Supports are most effective when young people are encouraged to take action themselves and be involved in decision-making. This chapter makes clear-as is the case throughout the book-the challenges faced by the current restrictions of refugee policy, in particular the lack of support for community agencies.

This book is an effort to comparatively study the resettlement landscape in English-speaking countries in the Global North. What emerges is a nuanced portrait of the challenges of integration for refugees and concrete suggestions for developing better models of service delivery. Although helpful to focus on countries that have similar integration systems, omitting countries outside of the Global North does inscribe developmentalist North/South divides. In this regard, future research might consider the many ways in which people are creating local response structures, including more informal forms of hospitality in major refugee hosting contexts outside the Global North. At the same time, future researchers may also wish to reflect on forms of resettlement available not just for government-assisted refugees. Ontario's new Conservative government recently announced that no support will be provided for the costs associated with asylum seekers crossing from the United States. In this context, it is important to understand the integration landscape for arrivals outside of institutional resettlement responses. Certainly this book has exciting implications for future research avenues. Its rich ethnographic detail and theoretically attuned exploration of the dynamics of refugee settlement and integration will make it invaluable to scholars, practitioners, and policy-makers interested in forced migration and resettlement across the social sciences and humanities.

Julia Morris is a post-doctoral fellow in the Zolberg Institute on Migration and Mobility at the New School. The author may be reached at julia.morris@newschool.edu.

\section{Asylum after Empire: Colonial Legacies in the Politics of Asylum Seeking

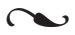 \\ Lucy Mayblin \\ Lanham, MD: Rowman and Littlefield International, 2017, 200 pp.}

$\mathrm{L}$ ucy Mayblin's book offers a sociological history of asylum policies in Great Britain through a post-colonial and a de-colonial approach that defines the refugee as "the embodiment of the darker side of modernity and of the global fallout of colonialism" (3). The first of eight chapters provide an excursus of Great Britain's toughening laws against migration during the 1990s, which stemmed from the government's approach to the 1951 Geneva Refugee Convention and the related 1967 Protocols. The author builds on Chimni's " "myth of difference," according to which there were no non-EU migrants moving toward Great Britain after the massive displacement of the Second World War. Drawing 
on Orchard's" "non-entrée regime," the book illustrates how the U.K. government prevented people from migrating, working, or living in the cities of their choosing (2-3). Since most migrants in the United Kingdom originally came from Britain's former colonies, the author emphasizes the need to rethink the history of asylum as non-European-a detail that studies on forced migration missed as stemming from imperialist foundations. The multiple histories of displacement need to be incorporated into a European understanding of the history of asylum. This introductory chapter therefore paves the way for an in-depth analysis of the "hostility of the British state" to post-colonial asylum seekers.

In chapter 2 Mayblin reminds us that the 1951 Refugee Convention had been drafted for the European refugees of the two world wars (1915-18 and 1939-45), and the Eastern Europe refugees of the Cold War were instead relatively few. Against this historical scenario, refugee crises are today portrayed as a "problem." Configuring her critique as a "sociology of absences," the author examines how non-European refugees at the gates of Europe in the 1990s were depicted as "different"; she argues that they were deliberately excluded from the refugee conventions as though they did not exist (24). Non-European refugees did not come from the modern world and were therefore believed to have a status other than that of "refugee." Mayblin's important association between modernity and refugeehood often goes unheeded in the scholarly literature, as does the contribution of colonialism to modernity. As a result, according to the author, there is a lack of contemporary accounts that strongly connect refugeehood to coloniality.

In chapter 3 Mayblin discusses how coloniality, rather than race, lies at the basis of today's anti-asylum attitudes. This chapter engages with discussions of the policies of labelling migrants (31), but the way Mayblin tackles the relationship between economic migration and forced migration remains slightly unclear. Her key argument is that it is not possible to categorize refugees on a racial basis; asylum seeker is a legal term that is not discriminatory in terms of ethnicity, religion, race, or gender. However, the modern colonial approach marks out refugees as "different"; asylum seekers are out of place in the spatial organization of modernity (39). While this statement is crucial to understand Mayblin's thinking, she explains in full what modernity means to her-the "right to humanity"-only later in the book, leaving the reader unsure about her conceptual framework during the early chapters.

To epistemically frame international politics in terms of coloniality and modernity, in chapter 4 the author examines the differential rights to humanity that lead to a human hierarchy. Britain's understanding of the "other" is applied to those who come from outside Europe (52). Non-white bodies are accorded a humanity according to criteria that range from biological to cultural and civilizational (77) attributes. The abolition of slavery-which the British government used to consider a source of sustainable viability - was a historical moment of rupture in the prevailing conceptions of humanity (81). While there is surely a racial element in the hierarchical ordering of human worth, for Mayblin, human beings are organized around ideas, cultures, civilizations, and religions, rather than the biological essence of racial ascription.

Chapter 5 outlines a history of the agreements enacted between colonial countries such as the 1919 Paris Agreement that led to the new League of Nations, the post-First World War peace settlement. However, I would have preferred to see a deeper explanation of how ending this human hierarchy "is not so much about race, but the motivations of racists and the obstacles they impose" (90). Mayblin mentions the post-First World War attempt to establish a transformative institutional order, when the Japanese delegation's proposal to introduce a racial equality clause was rejected. Japan could not be treated as equal to white supremacists, and in fact faced discrimination in Great Britain and other white settler colonies (109).

Chapter 6 reasserts how the dismantling of colonialism and the subsequent reshaping of the world order entailed mass displacements outside Europe (114). The chapter recapitulates how, in the post-war period, the British government did not want to grant human and refugee rights to nonEuropean refugees, particularly colonial subjects, but was in favour of aiding non-European refugees excluded from the Refugee Convention. In this sense, the contemporary British asylum and refugee policy needs to be understood within a context of colonialism and decolonization (146).

In chapter 7 the author unravels the institutionalized dehumanization of asylum seekers, whereby asylum applicants' ethnic origins and their position in an imaginary racial hierarchy, rather than their numbers (148), provoke racial reactions in the post-Brexit era. Importantly, Mayblin associates the British government's ongoing "war on poverty" with the historical protection reserved to non-colonized populations. She delineates a solid legal history of asylum that can also serve as an analytical basis for informed activism.

Chapter 8 concludes the book by contending that it is paramount to rebuild a historical sociology of asylum to understand how "dehumanisation is possible by the state even in the post-racial policy language of the contemporary moment" (179). With this book Mayblin employs an unusual combination of coloniality, modernity, and race in forced migration debates, stimulating further questions on postBrexit Great Britain: do contemporary policies constitute an abandonment of Europe, or rather a rupture with the colonies by abandoning Europe? 
Mayblin's book may be conceptually challenging for those who are less familiar with cultural and post-colonial studies but will inspire academic and non-academic researchers and activists to engage with human rights and asylum-seeking policies in the Global North.

\section{Notes}

1 B.S. Chimni, “The Geopolitics of Refugee Studies: A View from the South," Journal of Refugee Studies 11, no. 4 (2009): 11-29.

2 Phil Orchard, A Right to Flee: Refugees, States, and the Construction of International Cooperation (Cambridge: Cambridge University Press, 2014).

Estella Carpi is a research associate in the Migration Research Unit, Department of Geography, University College London. Shecan be reached ate.carpi@ucl.ac.uk. 